Importance of snow and glacier meltwater for agriculture on the Indo-Gangetic Plain 


\section{Supplementary Methods}

We use a coupled cryosphere-hydrology-crop model to analyse the spatial and temporal links between water supply generated upstream and crop specific water demand for agriculture in the downstream plains.

\section{Mountain hydrology, snow and glacier melt}

The hydrology in the upstream mountainous parts of the Indus, Ganges and Brahmaputra Basins is simulated using the physically-based fully distributed Spatial Processes in HYdrology (SPHY) cryospheric-hydrological model ${ }^{1}$. This model is the state-of-the-art for the simulation of cryospherichydrological processes at large river basins scale in Asia and has been applied in the upper Indus, Ganges and Brahmaputra basins in previous work ${ }^{2,3}$. SPHY has been specifically developed for application at large river basin scale under data scarce conditions. The setup used in this study is discussed in ${ }^{3}$.

In this study, the model runs at $5 \times 5 \mathrm{~km}$ spatial resolution and at a daily time step. Daily discharge is simulated by a) calculating total runoff for each grid cell as the sum of four different components: glacier runoff, snow runoff, rainfall runoff (i.e. the sum of surface runoff and lateral flow), and baseflow, and b) routing the total runoff and its components downstream, using a simplified routing scheme that requires a digital elevation model (DEM) and a recession coefficient. The total runoff $\left(Q_{\text {TOT }}\right)$ is calculated for each time step:

$$
Q_{T O T}=Q_{G M}+Q_{S M}+Q_{R R}+Q_{B F}
$$

where $Q_{G M}$ is glacier-melt runoff, $Q_{S M}$ is snow-melt runoff, $Q_{R R}$ is rainfall runoff, and $Q_{B F}$ is baseflow.

For the estimation of the contribution of snow and glacier melt to runoff, sub-grid variability (i.e. on $100 \times 100$ m resolution) is taken into account. The sub-grid variability is determined by a fractional ice cover ranging between 0 (no ice cover) and 1 (complete ice cover) which is assigned to each $5 \times 5$ $\mathrm{km}$ model grid cell. For each glacier, or a part thereof, within a $5 \times 5 \mathrm{~km}$ model grid cell, glacier information is added: glacier mean elevation, initial ice-thickness, and the type of glacier (i.e. debrisfree or debris-covered). The type of glacier is determined based on thresholds for slope and elevation ${ }^{4}$. Initial ice thicknesses are estimated according to the GlabTop2 methodology ${ }^{5}$. Glacier melt is calculated according to a degree-day approach ${ }^{6}$, where different factors are applied on debris-free and debris-covered glaciers. The produced meltwater is subsequently subdivided over the surface runoff and baseflow pathways by a calibrated glacier runoff fraction. Changes in the fractional glacier cover in response to changes in temperature and precipitation are taken into account using a mass conserving algorithm for ice redistribution.

Snow accumulation is modelled based on the daily precipitation and temperature threshold to distinguish between rain and snow. Snow melt is simulated using the degree-day approach of Hock ${ }^{6}$ and sublimation is estimated a simple elevation-dependent potential sublimation function ${ }^{7}$. The snow module incorporates refreezing and water storage in the snow pack. If the liquid storage in the 
snow pack exceeds the threshold, snow runoff is generated. The liquid and dry snow storage is updated daily and the result of all in and outgoing fluxes. Rainfall-runoff is calculated as saturation excess runoff. For the root zone layer the actual evapotranspiration is calculated using the Modified Hargreaves reference evapotranspiration equation ${ }^{8}$ and a land use dependent crop coefficient. Lateral flow of water in the soil between cells, exchange of water between soil layers and the groundwater reservoir through percolation and capillary rise, as well as the release of baseflow from the groundwater reservoir are simulated as described in Terink et al ${ }^{1}$.

\section{Downstream hydrology, irrigation water demand and supply}

For the simulation of downstream water availability, agricultural water demand and crop production we use the Lund Potsdam Jena managed Land model (LPJmL) ${ }^{9}$. LPJmL simulates the coupled hydrology and carbon cycles, which makes it a very suitable tool to study the interactions between water availability and food production ${ }^{10}$.

LPJmL simulates the daily water balance at sub-grid scale. Water enters the grid cell through precipitation or irrigation and is first diverted into direct surface runoff and infiltration into the soil. Subsequently, the water percolates through 5 soil layers of variable thickness, or enters the river system as subsurface runoff when soil water content exceeds saturation. In addition, water leaves the soil by evaporation from the upper $20 \mathrm{~cm}$ soil layer, or via transpiration by natural vegetation or crops from the first 2 soil layers ${ }^{11}$. The generated runoff enters the river system, through which it flows with a constant flow velocity of $1 \mathrm{~m} / \mathrm{s}^{12}$. The effect of large reservoirs on streamflow and water supply for irrigation is simulated by a simple generic reservoir operation scheme, in which different operating rules are implemented for irrigation reservoirs and reservoirs with other purposes ${ }^{13}$. The majority of the reservoirs in the Indus, Ganges, Brahmaputra Rivers and the rest of India, are built to store and supply water for irrigation. Although all those reservoirs have their own individual operation schemes, this information is often not accessible. Outflow regimes are therefore defined based on the size of the reservoir and the main purpose of the reservoir. Command areas of irrigation reservoirs are assigned based on elevation and distance to the reservoir as in Biemans et al. $(2011)^{13}$.

Irrigation occurs between the sowing and harvesting of irrigated crops. Crop specific daily irrigation demand is calculated as the minimum amount of water needed to fill the upper soil to field capacity and the amount needed to fulfil the atmospheric demand. Subsequently, the withdrawal demand is calculated by accounting for losses during conveyance, distribution, and application of water, depending on the type of irrigation system installed (surface, sprinkler or drip) and the soil type of the irrigated cell. We assume that all irrigated cropland in the Indus, Ganges and Brahmaputra Basins is sustained by surface irrigation systems ${ }^{14}$. The irrigation module is described in detail by Jägermeyr et al $^{15}$.

Irrigation water is withdrawn from surface water first. This is the water available in the river and natural lakes of the cell where the irrigated cropland is located, a neighbouring cell or available through the extensive canal systems of the Indus and Ganges Basins (see below). If an artificial 
reservoir with irrigation supply purpose is in reach of the irrigated fields, water can also be withdrawn from those reservoirs ${ }^{13}$. If the irrigation withdrawal cannot be fulfilled by the available surface water, water is withdrawn from groundwater, leading to depletion when withdrawal exceeds recharge (see below).

Rain fed and irrigated crop growth is simulated based on daily assimilation of carbon in four pools: leaves, stems, roots and harvestable storage organs. The amount of carbon allocated to those pools depends on crop phenology and is adjusted in case of water stress on the plants. Crops are harvested when either maturity or the maximum number of growing days is reached ${ }^{16,17}$.

Water resources availability and demand in South Asia are to a large extent governed by processes that are not accounted for in the global version of LPJmL ${ }^{9}$. To improve our understanding of the specific processes leading to water stress in this region, we have made a few adjustments to the original version of the model.

Important processes in mountain hydrology, such as glacier and snow accumulation and melt, and variable flow velocity due to different slopes, are not well represented in LPJmL. At the same time, large scale irrigation is not a dominating process in the hydrology in the mountains. Therefore, the upstream hydrology is simulated by the SPHY model (see above) ${ }^{1}$. To establish the coupling between the upstream domain simulated by SPHY and the downstream domain simulated by LPJmL, the mountain region is excluded from the LPJmL simulations and daily discharges of 27 sub-catchments of the upper Indus, Ganges and Brahmaputra are fed into LPJmL at the corresponding inlet points (see also Wijngaard et al., 2018). This coupling allows us to investigate where and when water that is generated upstream is important for the downstream water supply.

Besides a better simulation of the timing of water availability, we have improved the temporal representation of water demand by introducing double cropping with crop specific, monsoon dependent sowing dates in the LPJmL model ${ }^{18}$. This explicit representation of water demand timing improves our understanding of which crops need water when, and the water source they depend on. Moreover, we have improved our simulations of water demand compared to the previous version by explicitly accounting for the cultivation of cotton, which is particularly important in Pakistan.

Large parts of the floodplains of the Indus, Ganges and -to a lesser extent- the Brahmaputra river basins are equipped with an extensive system of irrigation canals, that deliver water to large command areas and can transport water over hundreds of kilometres. We added a representation of those canal systems in LPJmL to be able to simulate this important means of water supply. First, the most important irrigation canal systems in the Indus, Ganges and Brahmaputra river basins were mapped, and subsequently connected to corresponding command area inlet points at the main river. We simulate extraction of irrigation water from the main inlet points of the canal system and supply to the corresponding irrigated fields in the command area downstream.

Another important source of supply for irrigation in South Asia is groundwater. We have introduced a simple groundwater module in LPJmL to be able to estimate depletion rates. A groundwater store in each cell is filled by daily groundwater recharge, which equals the water percolating through the 
lower soil layer. Subsequently, this groundwater can be extracted for irrigation if surface water is insufficiently available. Next to that, the groundwater is contributing to base flow. A linear reservoir algorithm with an average residence time of 100 days controls the base flow of the grid cell as in ${ }^{19}$. When long term groundwater withdrawals exceed the recharge, groundwater tables drop too far to contribute to base flow, withdrawals are unsustainable and lead to depletion as in 20 .

LPJmL crop yields for the most important food crops were calibrated against subnational (for India and Pakistan) agricultural statistics as in Biemans et al (2016) ${ }^{18}$ (see below).

Finally, we have increased the spatial resolution of the simulations to 5 minutes grid cells (around $8 * 8$ kilometres), which leads to a better delineation of sub-basins and more detailed representation of soil types, land use, state boundaries and canal systems.

\section{Input data}

\section{Climate data}

LPJmL is forced with daily mean air temperature, precipitation, long and shortwave radiation. A 1000 year spin up run forced by a climate dataset developed by applying the Watch Forcing Data methodology to the ERA-Interim Reanalysis data (WFDEI) ${ }^{21}$ is used to bring the carbon pools in equilibrium. Subsequently, the model is forced with the recently developed reference climate dataset for the Indus, Ganges and Brahmaputra river basins ${ }^{22}$. This forcing dataset is based on the WFDEI data set, but is downscaled to $5 \times 5 \mathrm{~km}$ resolution for the upstream basins and $10 \times 10 \mathrm{~km}$ for the downstream basins using high resolution elevation data. For the upstream basins an additional correction for the underestimation of high-altitude precipitation has been incorporated using glacier mass balance data as a proxy to estimate actual precipitation amounts ${ }^{23,24}$. To run LPJmL, the dataset has been re-gridded to a 5 min regular lat-lon resolution.

$\mathrm{SPHY}$ is forced with daily precipitation, mean, maximum and minimum air temperature from the same reference climate dataset.

Soil

The soil data for LPJmL was derived from the Harmonized World Soil Database ${ }^{25}$, from which we used the 13 classes of the USDA texture classes. The original data was re-gridded to a 5 minute resolution, based on a majority rule.

For the SPHY-model, soil information is derived from HiHydroSoil ${ }^{26}$, which is a high-resolution map of hydraulic properties, derived from the Harmonized World Soil Database ${ }^{25}$ using pedo-transfer functions.

\section{Landuse}

For LPJmL, gridded fractions of 12 rain fed and irrigated crops for the kharif and rabi seasons are derived from MIRCA2000 ${ }^{27}$ as in Biemans et al.(2016) ${ }^{18}$, but not aggregated to 30 minute resolution. Moreover, we have added cotton as an explicit crop growing during the early kharif 
season, rather than simulating big areas covered with cotton as perennial other crops. Especially in the Indus basin, irrigated cotton has a large share in the total irrigation water withdrawal.

Supplementary figure 3 shows distributions of four of the most important crops.

Land use classes in the SPHY model are taken from GlobCover, resampled to $5 \times 5 \mathrm{~km}$ resolution ${ }^{28}$.

\section{Glaciers}

Glacier outlines for the SPHY model are derived from the Randolph Glacier Inventory v5.0 ${ }^{29}$ and are gridded to a $100 \times 100 \mathrm{~m}$ grid. The glaciers are intersected with the model grid and for each glacier model grid cell combination a unique ID, a debris flag and the elevation is assigned.

\section{Sowing dates}

Sowing dates are implemented as in Biemans et al. (2016) ${ }^{18}$. Kharif crops are assumed to be sown 5 days after the onset of the monsoon, and therefore depend on the location. An exception is made for cotton, which is sown in April in the whole region except for the Punjab region in Pakistan, where it is sown on the $1^{\text {st }}$ of May ${ }^{27}$. Rabi crops are sown on the $1^{\text {st }}$ of November in the whole region.

\section{Drainage}

The drainage direction of rivers is derived from the HYDROshedS global database ${ }^{30}$ for both SPHY and LPJmL. For the downstream model (LPJmL) we used the 5 minute version of the drainage direction map, which is available from the authors (Lehner, personal communication).

\section{Reservoirs and elevation}

Human built reservoirs alter the natural flow regime of a river. The effect on streamflow depends on the size of the reservoir behind the dam, as well as the purpose of the dam. Some dams are built purely to supply irrigated areas, others are built generate hydropower, and some dams have multiple purposes at the same time. Data on the location, purpose and capacity of dams is taken from the Global Reservoirs and Dams database (GRanD), which is the most comprehensive geographically referenced database available at global scale ${ }^{31}$. Reservoir operation rules are implemented as in Biemans et al. (2011) ${ }^{13}$.

\section{Model performance}

\section{Discharge}

The upstream model is calibrated and validated using a two-step systematic approach. In this approach, first model parameters related to glacier and snow processes are calibrated to MODIS remote sensing snow cover ${ }^{32}$ and geodetic glacier mass balance data. Secondly, remaining model parameters are calibrated to observed discharge, at six gauging locations; two in each river basin. With this two-step approach, equifinality problems common for the simulation of high mountain hydrology are minimized ${ }^{33}$. The model performance is validated at the same locations, for other periods than the calibration. A comparison of simulated and observed monthly discharge (multi-year 
averages covering the full calibration and validation periods) is shown for the three most downstream locations (Besham Qila in the Indus, Devghat in the Ganges, Sunkosh in the Brahmaputra), covering the largest part of the SPHY model domain, in supplementary figure 4 . The calibration/validation approach and results are described in detail in Wijngaard et al. ${ }^{3}$. The performance of the coupled SPHY-LPJmL model in simulating discharge is validated at three downstream gauging locations, close to the outlets of the three river basins (Kotri barrage in the Indus, Hardinge Bridge in the Ganges, and Bahadurabad in the Brahmaputra, supplementary table 1). Locations close to the station outlets have been selected to cover effects of human impacts such as flow alterations through reservoir operations and water withdrawals (for locations of the downstream stations, see figure 1 of the main article). A comparison of simulated and observed monthly discharge (multi-year averages) is shown in supplementary figure 4.

For the majority of stations, the model performance is satisfactory to very good with Nash-Sutcliffe Efficiencies ${ }^{34}$ above 0.6 and up to 0.83 , and biases below $\pm 25 \%{ }^{35}$ (supplementary table 1 ). Exceptions are the location Kotri Barrage, where model performance is unsatisfactory, and the $34 \%$ bias at Hardinge bridge is also considerable. The poorer model performance at Kotri Barrage suggests losses from the river (water abstraction for irrigation, evaporation and infiltration) are underestimated. We estimate river infiltration and evaporation cannot explain the difference. At the same time, the simulated irrigation water withdrawals in Pakistan is higher than most other estimates $^{18}$. We chose to keep water withdrawal estimates as close as possible to other estimates.

\section{Crop yields}

Crop yields have been calibrated against subnational agricultural statistics for the years 2003-2008 (figure S5). The calibration is done by varying three coupled parameters that represent management intensity: maximum leaf area index, maximum harvest index and a parameter to scale leaf-level biomass production to grid level. Applying a sub-national calibration of crop yields, allows for a representation of spatial heterogeneity in crop yields as a result of different management practices, in addition to the variations caused by differences in climate. The subnational calibration is described in more detail in Biemans et al. (2016) ${ }^{18}$. In the current study however, we have added cotton, and merged the kharif and rabi yields into one single value for calibration.

Caloric content of crops are taken from food composition tables provided by FAO ${ }^{36}$.

\section{Modelling protocol}

To distinguish irrigation water supply originating from the mountains, and subsequently from snow and glacier melt, as well as to relate crop yields to the different water sources, we have made a series of simulations in which we switched off different sources of water supply:

1. A simulation where only surface water can be used for irrigation, assuming there is no water supply from the upstream mountains. Only the surface water generated in the plains can be used for irrigation. 
2. A simulation where all the downstream and the upstream surface water from base flow and rainfall runoff can be used for irrigation.

3. A simulation where all downstream and upstream generated surface water, including snow and glacier melt can be used for irrigation.

4. A simulation with irrigation supply from surface water and groundwater, assuming that groundwater is only applied when surface water is not available. In this simulation groundwater supply is not restricted, but will lead to depletion when groundwater withdrawal is larger than the groundwater recharge.

The model system is run for 1981-2010 at a daily time step.

The difference between run 2 and 3 determines the volumes of irrigation water withdrawal and crop yields that can be fully attributed to snow and glacier melt. Similarly, the difference between run 1 and 3 shows the water supply and related crop yields that can be related to water originating from the mountains. Run 4 is used to estimate total water withdrawal and crop yields, using all water sources in conjunction. 
A

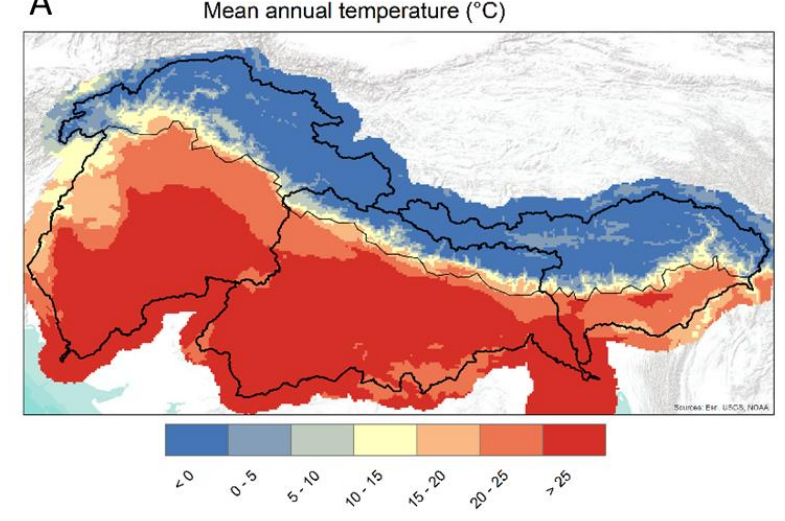

B

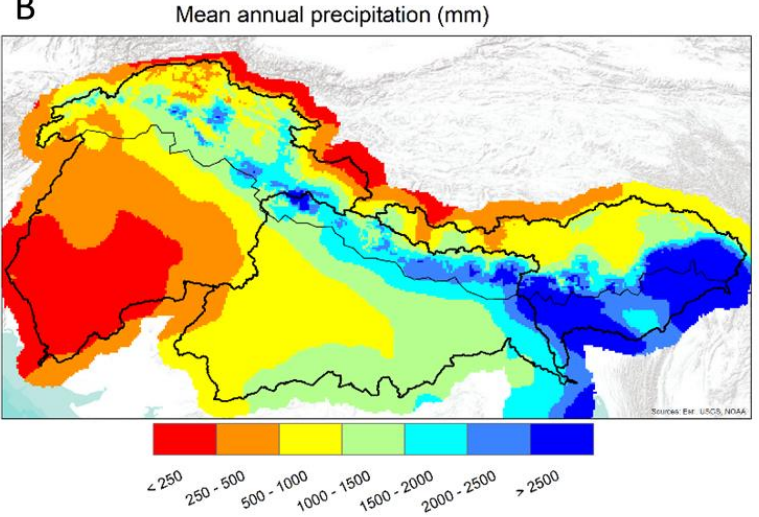

C

Indus

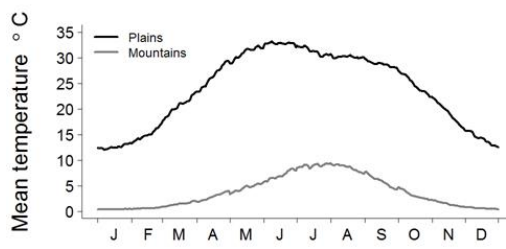

F

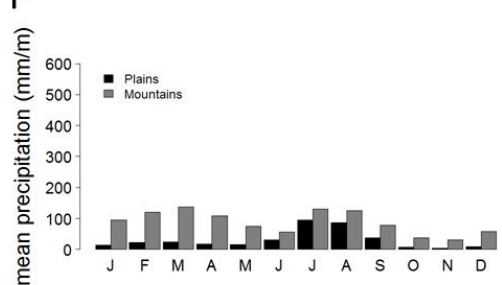

D

Ganges
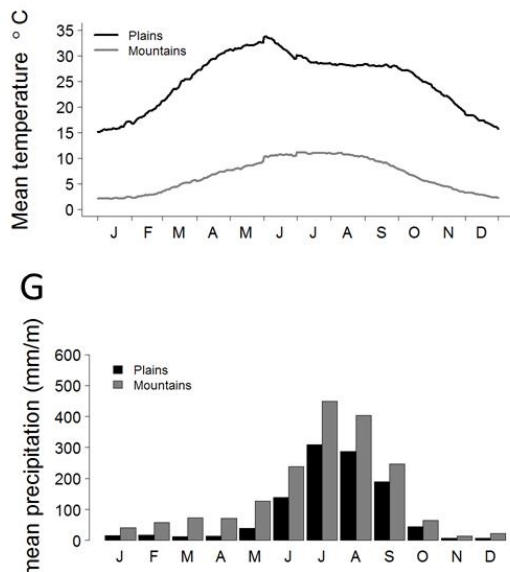

E Brahmaputra
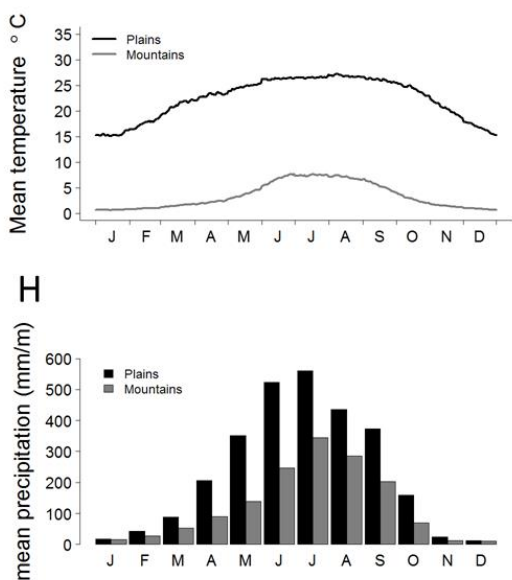

Supplementary Figure 1. Mean climate of the Indus, Ganges and Brahmaputra basins (1981-2010). A) Spatial variability in mean annual temperature (A), spatial variability in mean annual precipitation (B), mean annual cycles of temperature (C$E)$ and mean monthly precipitation $(F-H)$ in the mountains and plains for the Indus, Ganges and Brahmaputra basins respectively. Delineation of mountains and plains is indicated in panels A and B. Climate data from Lutz and Immerzeel ${ }^{22}$ 
Indus

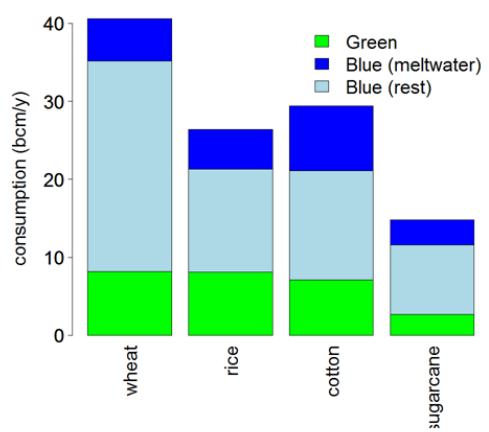

wheat
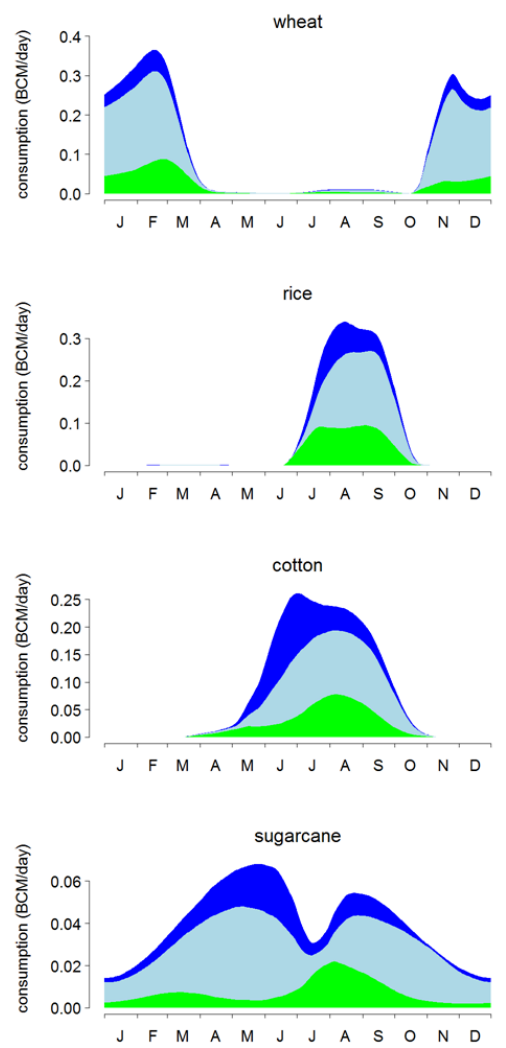

Ganges
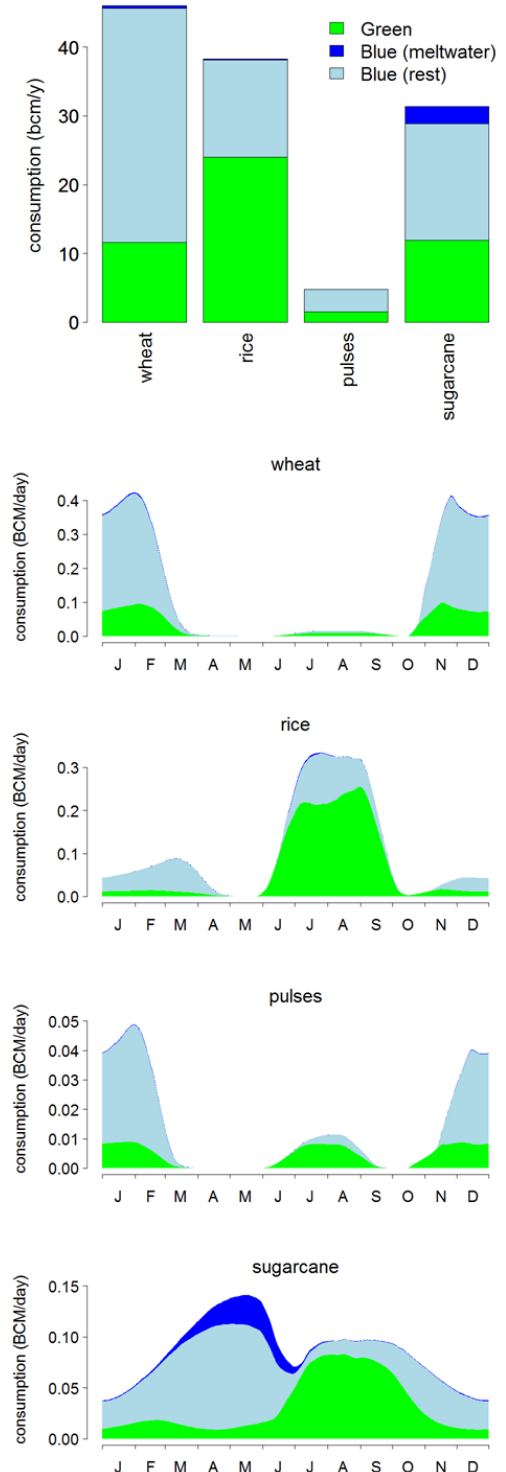

Brahmaputra

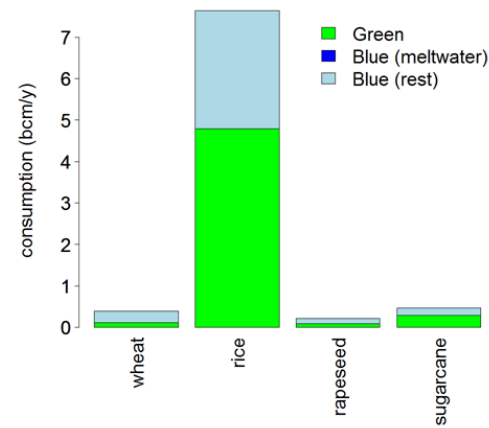

wheat
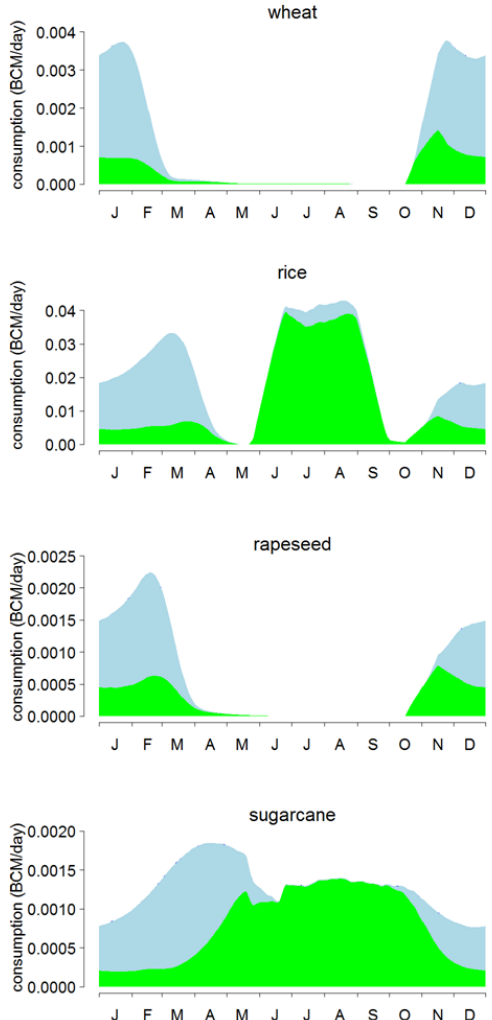

Supplementary Figure 2. Crop specific green and blue water consumption in irrigated agriculture. Mean annual green and blue water (meltwater and other blue water) consumption for the 4 most consuming irrigated crops per basin (upper panels) and daily mean blue and green water consumption for those crops (lower panels). 

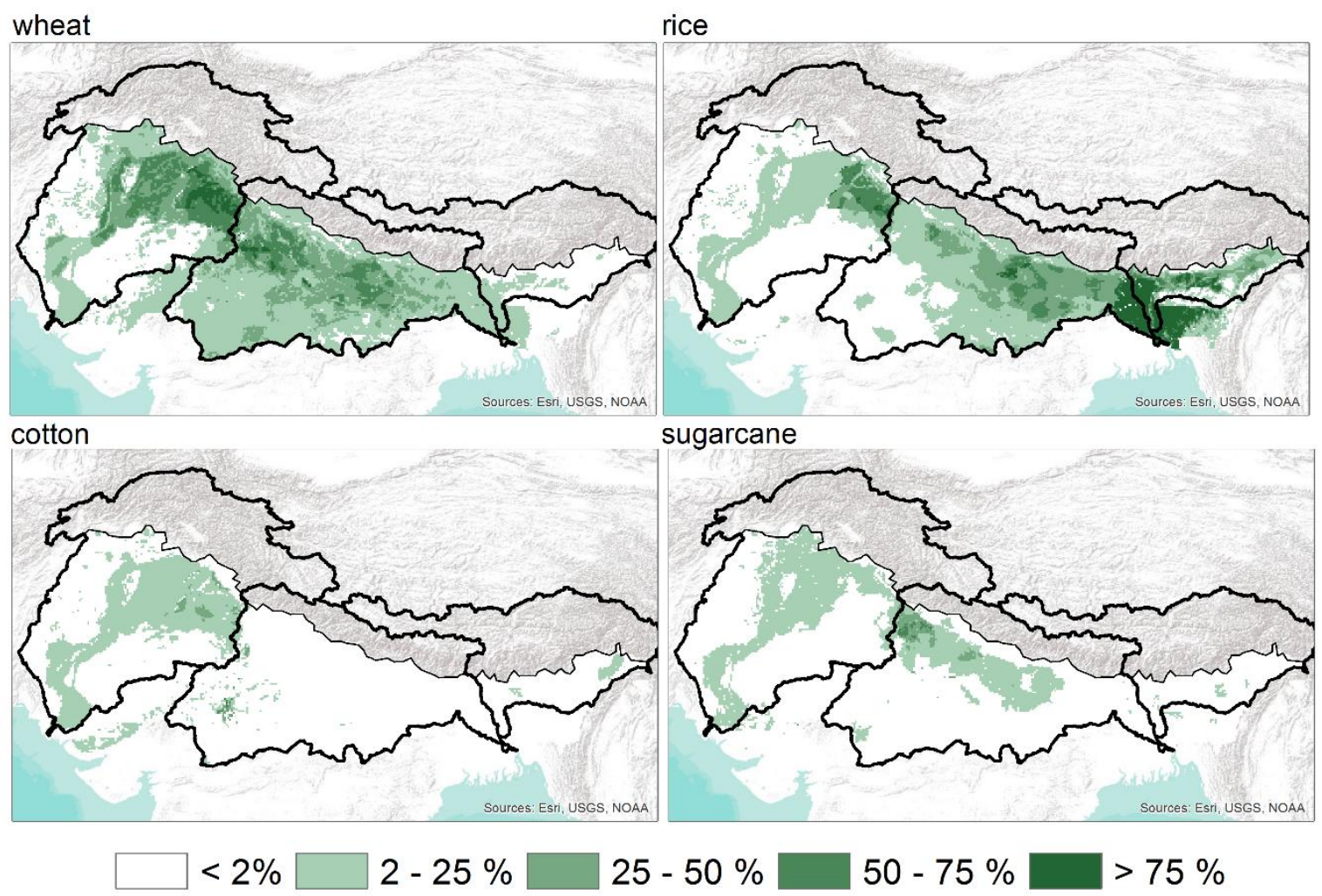

Supplementary Figure 3. Sown area of wheat, rice, cotton and sugarcane as percentage of the grid cell area. Other crops are included but not shown. 

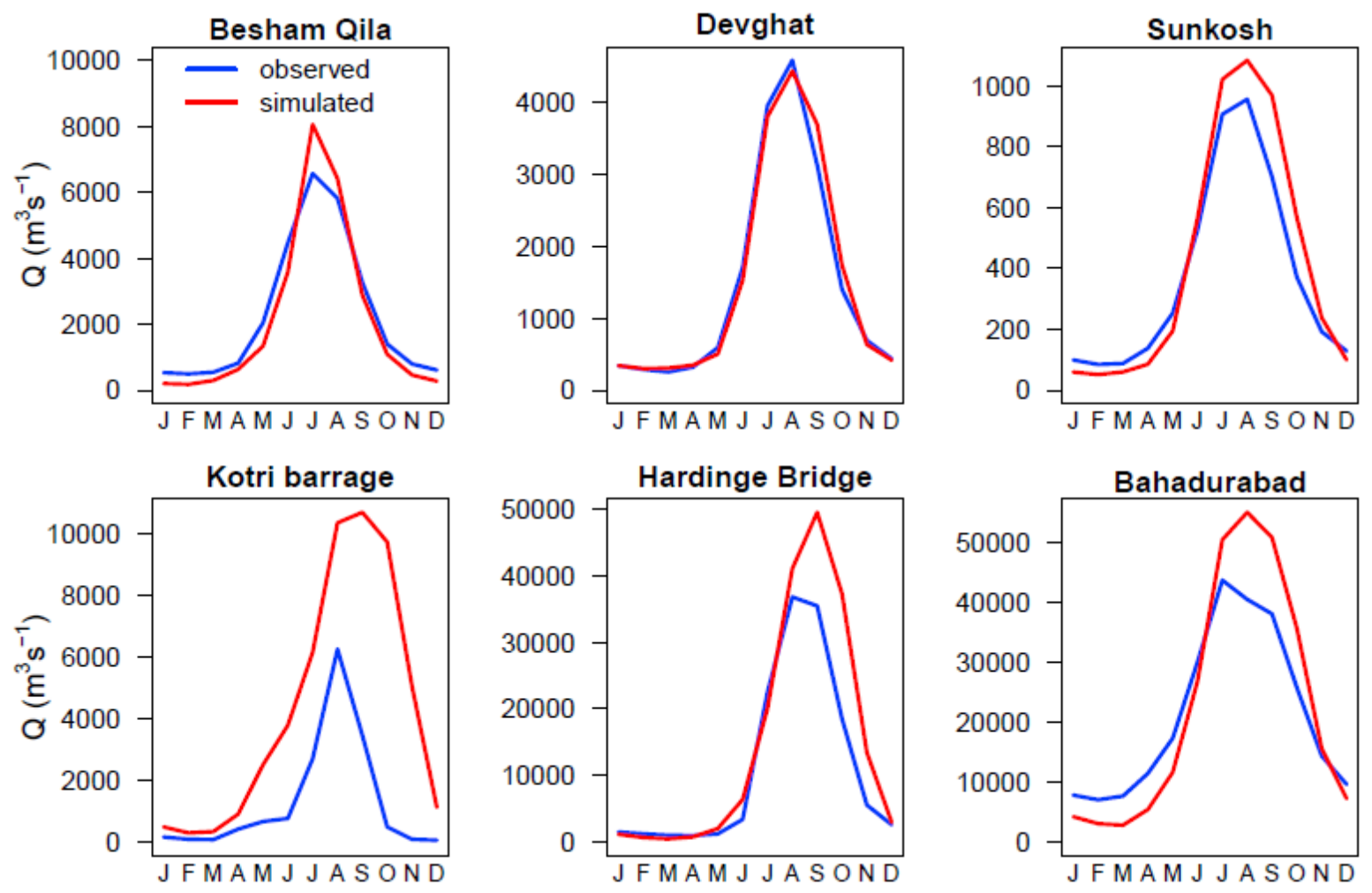

Supplementary Figure 4. Observed and simulated discharge at six locations in the model domain. Graphs show multi-year monthly averaged values for 2000-2008 (Besham Qila), 2000-2009 (Devghat), 1998-2008 (Sunkosh), 1981-2003 (Kotri Barrage), 2001-2010 (Hardinge Bridge), 1981-2008 (Bahadurabad). Periods were selected based on data availability.
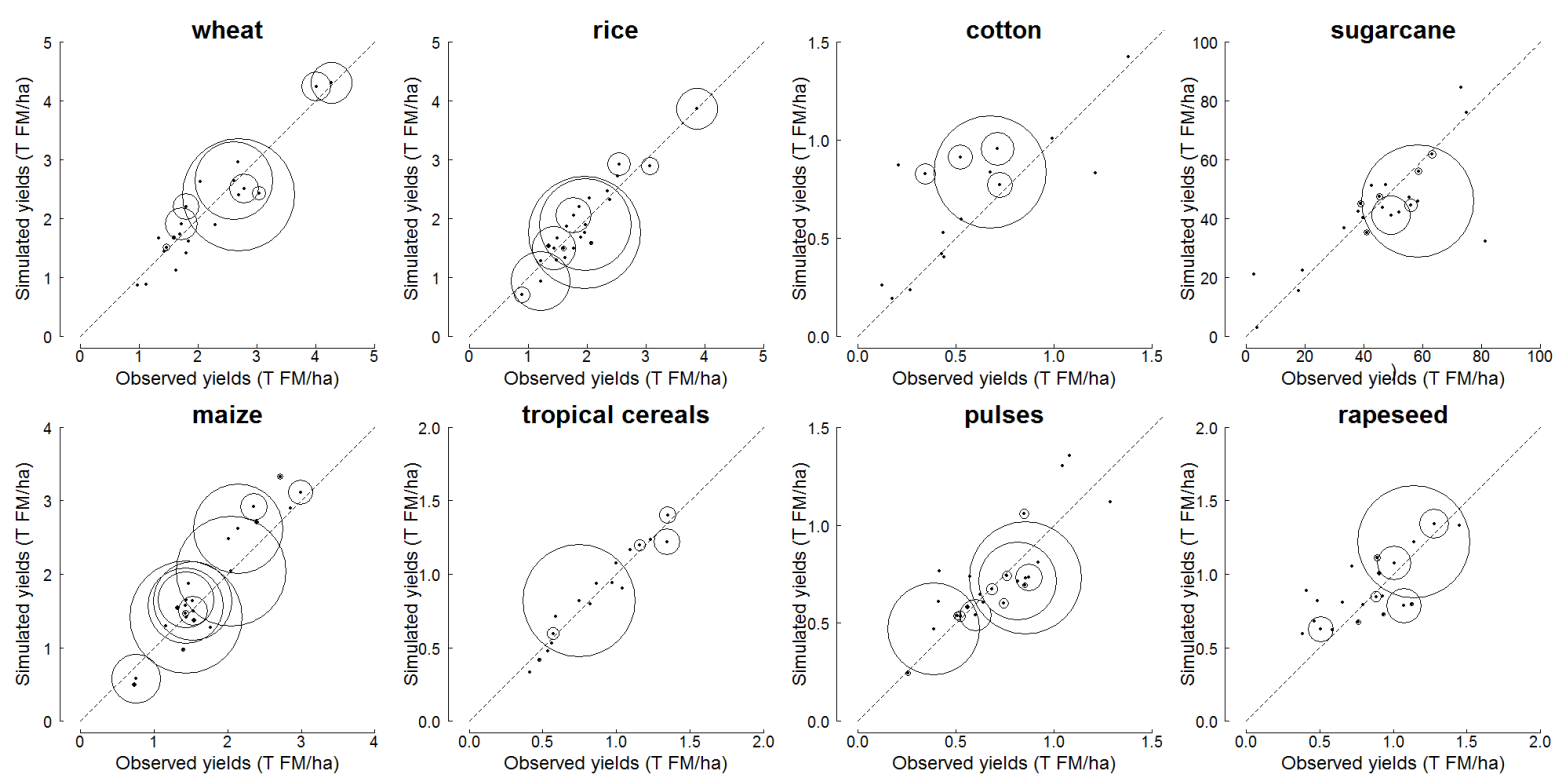

Supplementary Figure 5. Observed vs. simulated (calibrated) crop yields for the most important crops in tons of fresh matter per hectare (TFM ha-1). Each dot represents one state (India), province (Pakistan) or country (Nepal, Bangladesh).

Size of the circle represents the relative area under that crop in the respective administrative unit. 


\section{Mean annual groundwater depletion}

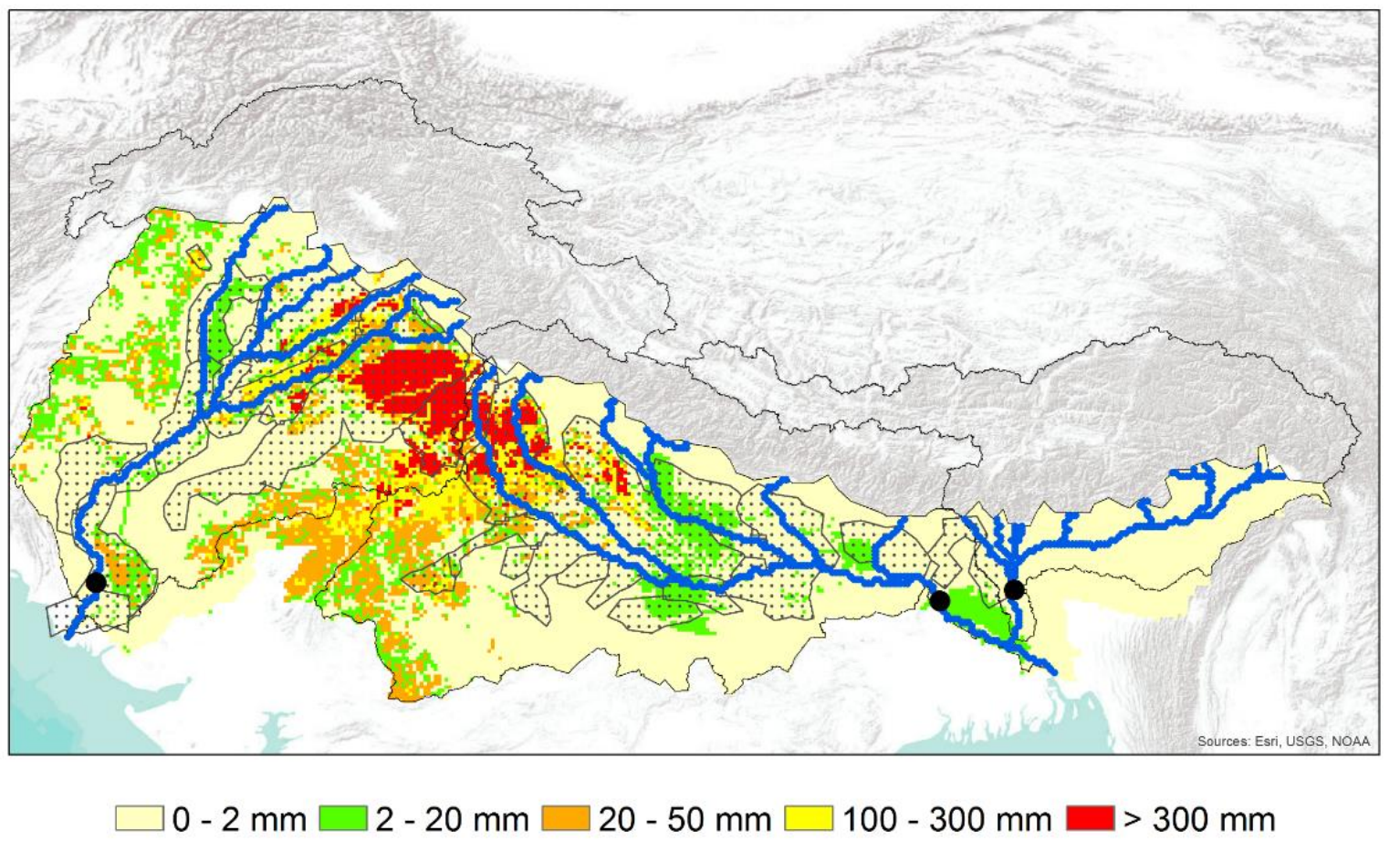

Supplementary Figure 6. Mean annual groundwater depletion $(\mathrm{mm})$ in the plains due to groundwater extractions for irrigation. Dotted polygons represent the command areas of the large scale irrigation canal systems through which water from the main river is diverted and distributed 


\section{Supplementary Tables}

Supplementary Table 1. Model performance indicators at six calibration/validation locations.

\begin{tabular}{|c|c|c|c|c|c|c|}
\hline & $\begin{array}{l}\text { Besham } \\
\text { Qila (upper } \\
\text { Indus)* }\end{array}$ & $\begin{array}{l}\text { Devghat } \\
\text { (upper } \\
\text { Ganges)* }\end{array}$ & $\begin{array}{l}\text { Sunkosh (upper } \\
\text { Brahmaputra)* }\end{array}$ & $\begin{array}{l}\text { Kotri } \\
\text { Barrage } \\
\text { (lower } \\
\text { Indus) }^{+}\end{array}$ & $\begin{array}{l}\text { Hardinge } \\
\text { Bridge } \\
\text { (lower }^{-} \\
\text {Ganges) }^{+}\end{array}$ & $\begin{array}{c}\text { Bahadurabad } \\
\text { (lower } \\
\text { Brahmaputra) }\end{array}$ \\
\hline $\begin{array}{l}\text { Location } \\
\text { (lon,lat) }\end{array}$ & $\begin{array}{l}72.87 \mathrm{E} \\
34.91 \mathrm{~N}\end{array}$ & $\begin{array}{l}84.44 \mathrm{E} \\
27.71 \mathrm{~N}\end{array}$ & $89.91 \mathrm{E}, 27.48 \mathrm{~N}$ & $\begin{array}{l}\text { 68.29E, } \\
25.30 \mathrm{~N}\end{array}$ & $\begin{array}{l}89.04 \mathrm{E} \\
24.06 \mathrm{~N}\end{array}$ & $89.70 \mathrm{E}, 25.13 \mathrm{~N}$ \\
\hline $\begin{array}{l}\text { Period for } \\
\text { calculation } \\
\text { of } \\
\text { performance } \\
\text { indicators }\end{array}$ & $2000-2008$ & 2000-2009 & $1998-2008$ & $1981-2003$ & 2001-2010 & $1981-2008$ \\
\hline $\begin{array}{l}\text { Nash- } \\
\text { Sutcliffe } \\
\text { Efficiency (-) }\end{array}$ & 0.66 & 0.84 & 0.71 & -0.47 & 0.74 & 0.63 \\
\hline Bias (\%) & -6.7 & 1.9 & 12.4 & 237.0 & 33.9 & 5.1 \\
\hline $\begin{array}{l}\text { Pearson's R } \\
(-)\end{array}$ & 0.89 & 0.91 & 0.90 & 0.70 & 0.91 & 0.95 \\
\hline
\end{tabular}

*Efficiencies calculated with daily values of observed and simulated discharge

+Efficiencies calculated with monthly values of observed and simulated discharge 
Supplementary Table 2. Total mean annual production of major crops (in MT Fresh Matter) in the three basins and the fraction of their yields that can be attributed to water originating from snow- and glacier-melt. Numbers are based on calibrated yields (supplementary figure 5) and validated crop areas (Biemans et al, 2016) at subnational scale.

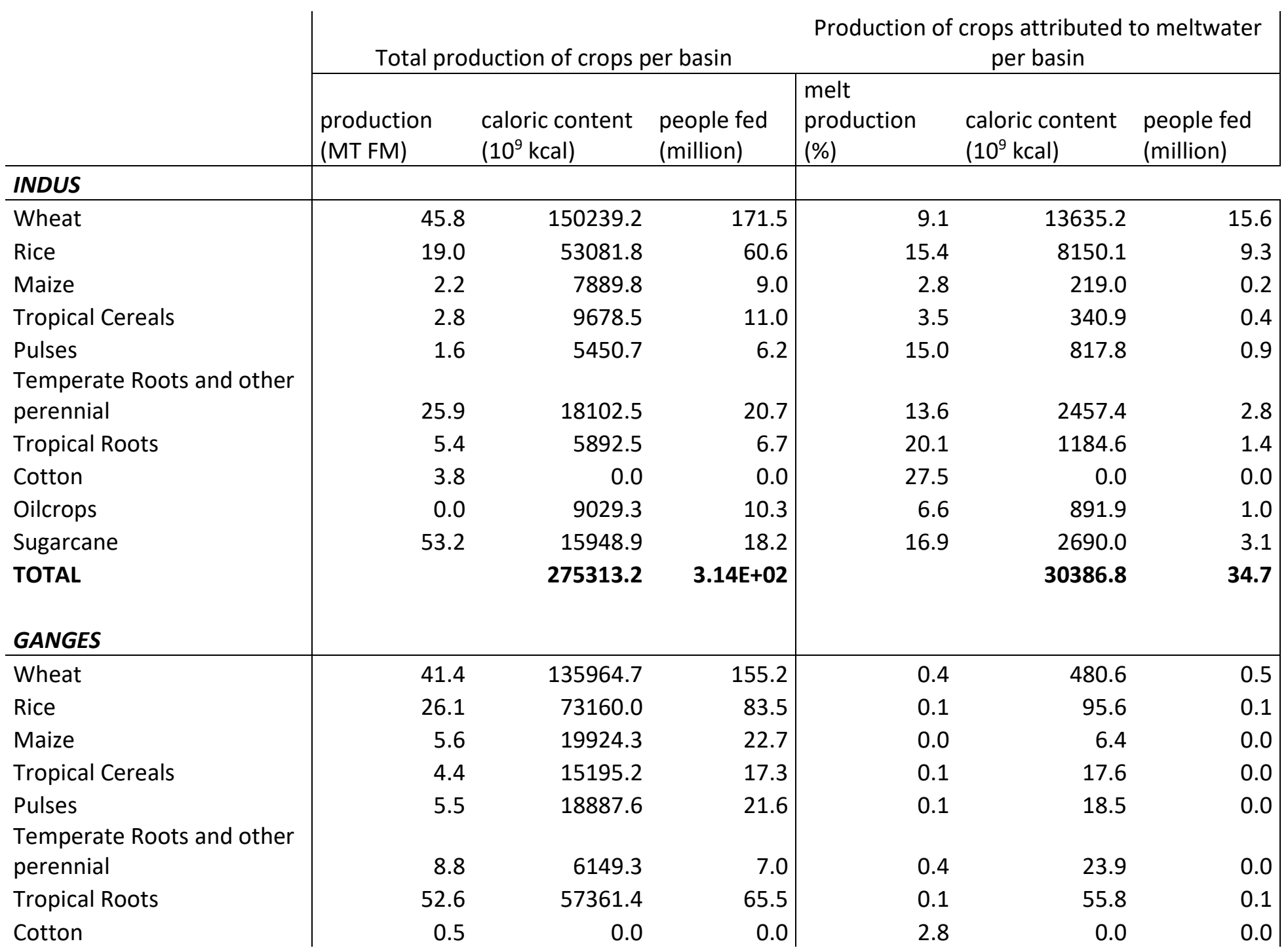




\begin{tabular}{|c|c|c|c|c|c|c|}
\hline Oilcrops & 3.9 & 11949.4 & 13.6 & 0.1 & 4.0 & 0.0 \\
\hline Sugarcane & 102.7 & 30810.0 & 35.2 & 6.5 & 1995.1 & 2.3 \\
\hline TOTAL & & 369401.9 & $4.22 E+02$ & & 2697.6 & 3.1 \\
\hline \multicolumn{7}{|l|}{ BRAHMAPUTRA } \\
\hline Wheat & 0.6 & 2105.9 & 2.4 & 0.0 & 0.0 & 0.0 \\
\hline Rice & 8.7 & 24265.1 & 27.7 & 0.0 & 0.0 & 0.0 \\
\hline Maize & 0.1 & 302.3 & 0.3 & 0.0 & 0.0 & 0.0 \\
\hline Tropical Cereals & 0.1 & 409.8 & 0.5 & 0.0 & 0.0 & 0.0 \\
\hline Pulses & 0.3 & 1059.6 & 1.2 & 0.0 & 0.0 & 0.0 \\
\hline Temperate Roots and other & & & & & & \\
\hline perennial & 1.1 & 799.0 & 0.9 & 0.0 & 0.0 & 0.0 \\
\hline Tropical Roots & 11.1 & 12086.1 & 13.8 & 0.0 & 0.0 & 0.0 \\
\hline Cotton & 0.0 & 0.0 & 0.0 & 0.0 & 0.0 & 0.0 \\
\hline Oilcrops & 0.4 & 1956.9 & 2.2 & 0.0 & 0.0 & 0.0 \\
\hline Sugarcane & 2.3 & 694.9 & 0.8 & 0.0 & 0.0 & 0.0 \\
\hline TOTAL & & 43679.5 & $4.99 \mathrm{E}+01$ & & 0.0 & 0.0 \\
\hline
\end{tabular}




\section{Supplementary References}

1 Terink, W., Lutz, A. F., Simons, G. W. H., Immerzeel, W. W. \& Droogers, P. SPHY v2.0: Spatial Processes in HY drology. Geosci Model Dev 8, 2009-2034, doi:10.5194/gmd-8-2009-2015 (2015). Lutz, A. F., Immerzeel, W. W., Shrestha, A. B. \& Bierkens, M. F. P. Consistent increase in High Asia's runoff due to increasing glacier melt and precipitation. Nat Clim Change 4, 587-592, doi:10.1038/Nclimate2237 (2014). Wijngaard, R. R. et al. Future changes in hydro-climatic extremes in the Upper Indus, Ganges, and Brahmaputra River basins. Plos One 12, e0190224 (2017). Paul, F., Huggel, C. \& Kääb, A. Combining satellite multispectral image data and a digital elevation model for mapping debris-covered glaciers. Remote Sens Environ 89, 510-518 (2004). Frey, $\mathrm{H}$. et al. Estimating the volume of glaciers in the Himalayan-Karakoram region using different methods. The Cryosphere 8, 2313-2333 (2014). Hock, R. Temperature index melt modelling in mountain areas. Journal of hydrology 282, 104-115 (2003). Lutz, A. F., Immerzeel, W., Kraaijenbrink, P., Shrestha, A. B. \& Bierkens, M. F. Climate change impacts on the upper Indus hydrology: Sources, shifts and extremes. Plos One 11, e0165630 (2016). Droogers, P. \& Allen, R. G. Estimating reference evapotranspiration under inaccurate data conditions. Irrigation and drainage systems 16, 33-45 (2002). Schaphoff, S. et al. LPJmL4-a dynamic global vegetation model with managed land-Part 1: Model description. Geosci Model Dev 11, 1343 (2018). Gerten, D. et al. Global water availability and requirements for future food production. Journal of Hydrometeorology 12, 885-899, doi:10.1175/2011jhm1328.1 (2011). Research Letters 8, 014026 (2013). Rost, S. et al. Agricultural green and blue water consumption and its influence on the global water system. Water Resources Research 44, doi:10.1029/2007WR006331 (2008). (ischans, $H$. et al. Impact of reservoirs on river discharge and irrigation water supply during the 20th century. Water Resources Research 47, doi:10.1029/2009wr008929 (2011). FAO. http://faostat.fao.org/, 2012). Jägermeyr, J. et al. Water savings potentials of irrigation systems: global simulation of processes and linkages. Hydrol. Earth Syst. Sci. 19, 3073-3091, doi:10.5194/hess-19-3073-2015 (2015). Bondeau, A. et al. Modelling the role of agriculture for the 20th century global terrestrial carbon balance. Global Change Biology 13, 679-706 (2007).

Fader, M., Rost, S., Müller, C., Bondeau, A. \& Gerten, D. Virtual water content of temperate cereals and maize: Present and potential future patterns. Journal of Hydrology 384, 218-231 (2010). Biemans, H., Siderius, C., Mishra, A. \& Ahmad, B. Crop-specific seasonal estimates of irrigation-water demand in South Asia. Hydrology and Earth System Sciences 20, 1971-1982, doi:10.5194/hess-201971-2016 (2016).

19 Alcamo, J. et al. Development and testing of the WaterGAP 2 global model of water use and availability. Hydrological Sciences Journal-Journal Des Sciences Hydrologiques 48, 317-337 (2003). Wada, Y. et al. Global depletion of groundwater resources. Geophysical Research Letters 37 doi:10.1029/2010GL044571 (2010).

21 Weedon, G. P. et al. The WFDEI meteorological forcing data set: WATCH Forcing Data methodology applied to ERA-Interim reanalysis data. Water Resources Research 50, 7505-7514, doi: $10.1002 / 2014 w r 015638$ (2014).

Lutz, A. F. \& Immerzeel, W. W. HI-AWARE Research Component 1. Reference Climate Dataset for the Indus, Ganges and Brahmaputra River Basins., (FutureWater, 2015). Immerzeel, W., Wanders, N., Lutz, A., Shea, J. \& Bierkens, M. Reconciling high-altitude precipitation in the upper Indus basin with glacier mass balances and runoff. Hydrology and Earth System Sciences 19, 4673 (2015) distribution of precipitation in the Hunza basin. Mountain research and development 32, 30-38 (2012).

\section{Italy and Laxenburg, Austria, 2012).} (2015). Portmann, F. T., Siebert, S. \& Doll, P. MIRCA2000-Global monthly irrigated and rainfed crop areas around the year 2000: A new high-resolution data set for agricultural and hydrological modeling. Global Biogeochemical Cycles 24, - (2010). Defourny, P. et al. in Proceedings of the ISPRS Commission VII mid-term symposium, Remote sensing: from pixels to processes. 8-11 (Citeseer). Arendt, A. et al. Randolph glacier inventory-a dataset of global glacier outlines: version 5.0. Global Land Ice Measurements from Space; Digital Media: Boulder, CO, USA (2015). Eos, Transactions American Geophysical Union 89, 93-94 (2008). 
Lehner, B. et al. High resolution mapping of global reservoirs and dams and their impact on

downstream rivers. Frontiers in Ecology and the Environment 9, 494-502 (2011).

32 Hall, D. K., Riggs, G. A., Salomonson, V. V., DiGirolamo, N. E. \& Bayr, K. J. MODIS snow-cover

33 Pellicciotti, F., Buergi, C., Immerzeel, W. W., Konz, M. \& Shrestha, A. B. Challenges and uncertainties in hydrological modeling of remote Hindu Kush-Karakoram-Himalayan (HKH) basins: suggestions for calibration strategies. Mountain Research and Development 32, 39-50 (2012).

34 Nash, J. E. \& Sutcliffe, J. V. River flow forecasting through conceptual models part I-A discussion of principles. Journal of hydrology 10, 282-290 (1970).

35 Moriasi, D. N. et al. Model evaluation guidelines for systematic quantification of accuracy in watershed simulations. Transactions of the ASABE 50, 885-900 (2007).

36 FAO. Food Balance Sheets, A Handbook. FAO: Rome, Italy (2001). 